\title{
Discrimination in ingestion of protistan prey by larval crabs
}

\author{
Shawn Hinz, Stephen Sulkin*, Suzanne Strom, Jill Testermann \\ Shannon Point Marine Center, 1900 Shannon Point Road, Anacortes, Washington 98221, USA
}

\begin{abstract}
We determined the incidence of ingestion of 4 autotrophic dinoflagellates and 1 heterotrophic dinoflagellate by first stage larvae of 4 species of crabs. Crab species were 2 winter spawning brachyurans Cancer magister and C. oregonensis, 1 summer spawning brachyuran Hemigrapsus oregonensis, and 1 anomuran Rhinolithodes wosnessenskii. Autotrophic dinoflagellate prey were Prorocentrum micans, which sustain survival of crab larvae in laboratory culture, and 2 species of Alexandrium spp. that do not. P. micans were ingested by virtually all larvae of all 4 crab species, while both toxic and non-toxic strains of Alexandrium were almost never ingested. Results of rearing experiments generally confirmed that larvae were receiving no nutritional contribution from Alexandrium spp. prey. When brachyuran larvae were presented with mixtures of $P$. micans and Alexandrium spp. in defined ratios, virtually all larvae ingested both types of algal prey. Suspending Alexandrium cells in $P$. micans exudate did not enhance their ingestion nor did suspending $P$. micans in Alexandrium exudate reduce ingestion. Ingestion of plastic beads was low $(<12 \%)$ except when offered in combination with $P$. micans cells $(58 \%)$. H. oregonensis larvae ingested the heterotrophic dinoflagellate Noctiluca scintillans that had previously fed on either P. micans or one of the toxic Alexandrium strains, with no apparent preference. Results suggest the presence of a positive ingestion stimulus provided by P. micans and N. scintillans, but its absence in Alexandrium spp. Absence of ingestion of Alexandrium was not related to the presence of toxins. The ingestion stimulus appears to reside on the prey cell surface. Although crab larvae appear able to discriminate among algal prey, non-discriminate feeding seems likely to occur in mixed prey assemblages in which at least some prey possess the positive ingestion cue, perhaps permitting rapid ingestion of available particles when dense prey patches are encountered in an otherwise sparse prey environment.
\end{abstract}

KEY WORDS: Protists $\cdot$ Crabs $\cdot$ Larvae $\cdot$ Nutrition $\cdot$ Prey discrimination

\section{INTRODUCTION}

Larvae of most species of brachyuran crabs are planktotrophic; that is, they must feed on particulate sources of nutrition in the plankton to develop successfully to metamorphosis. In addition to needing a source of energy to sustain metabolism, most species must obtain specific nutrients from the diet to maximize survival and development rate (Sulkin \& van Heukelem 1980, Levine \& Sulkin 1984).

Obtaining a source of nutrition early during the first larval (zoeal) stage is particularly important in pro-

${ }^{*}$ Corresponding author. E-mail: sulkin@CC.wwu.edu moting good survival during later zoeal stages (e.g. Anger \& Dawirs 1981, Staton \& Sulkin 1991, Hartman \& Sulkin 1999). Although brachyuran larvae have been thought to require relatively high densities of motile animal prey, Lehto et al. (1998) and Sulkin et al. $(1998 a, b)$ have shown that larvae of the crabs Cancer spp. and Hemigrapsus oregonensis ingest both autotrophic and heterotrophic protists and derive nutritional benefit from them. They speculated that while such diets alone may not be sufficient to sustain larval development, protists may be an important source of nutrition, sustaining first-feeding larvae until they encounter sufficient densities of suitable metazoan prey. This capacity to utilize the carbon 
sources of the microbial food web may be particularly important since suitable metazoan prey are often patchy in distribution and may not be present in sufficient densities to sustain larvae (Damkaer 1977, Paul et al. 1979, 1989).

However, while protists such as the autotrophic dinoflagellate Prorocentrum micans and the heterotrophic dinoflagellate Noctiluca scintillans have proved effective at providing nutrition to crab larvae, not all protists are. For example, the ciliates Euplotes vannus and Parauranema virginianum did not sustain development of larval crabs (Sulkin 1975). Further, larvae that were fed the ciliates Strombidinopsis acuminatum and an Uronema sp., the dinoflagellates Oxyrrhris marina, and 2 species of Alexandrium did not show higher survival than did unfed larvae (Sulkin unpubl. data). It is not clear whether these differences among protists as prey for crab larvae are due to selective ingestion on the part of the larvae or to differences in biochemical composition of the various prey.

The present study was designed to determine whether crab larvae are selective in their ingestion of different protists. We compared the ingestion of an autotrophic dinoflagellate known to sustain survival of crab larvae Prorocentrum micans with others that do not Alexandrium tamarense and $A$. fundyense. Use of Alexandrium spp. as experimental prey also permitted examination of larval ingestion of both toxic and nontoxic strains of an autotrophic dinoflagellate.

\section{MATERIALS AND METHODS}

Experimental protocol. Experiments were conducted to determine whether newly hatched larvae of 4 species of crabs would ingest cells of target protists provided individually and in various combinations. Ingestion was determined by direct observation of larval guts as described below.

Diet treatments included 2 autotrophic dinoflagellates that, although different in shape and volume, are approximately the same diameter (35 to $50 \mu \mathrm{m})$. Prorocentrum micans (strain UTEX 1993), previously shown to sustain crab larvae in laboratory culture (Lehto et al. 1998, Sulkin et al. 1998b), was used as a control diet. Two species of Alexandrium (shown not to sustain larval development in preliminary tests) were used in the experiments: A. fundyense 1719 (Af1719), a strain shown to be toxic in mouse bioassays, and 2 strains of $A$. tamarense, 1 toxic (At118) and 1 non-toxic (At115) (Teegarden \& Cembella 1996). All phytoplankton strains were obtained from the National Center for Collection of Marine Phytoplankton (Bigelow Laboratory, West Boothbay Harbor, ME). The toxicity of the strains used in the present study was confirmed by standard mouse bioassay procedures before and at the conclusion of the experiments.

Crab species tested were 3 brachyurans, the 2 winter spawners Cancer magister and C. oregonensis and the summer spawner Hemigrapsus oregonensis. An anomuran lithodid, Rhinolithodes wosnessenskii, was included because its larvae are facultative planktotrophs, able to feed but not requiring an external source of nutrition to survive.

Larvae were fed both single and mixed-species algal diets as well as combinations of algal cells and plastic beads, and algal cells immersed in the freshly prepared exudates of other phytoplankton species. In addition, larvae were fed the heterotrophic dinoflagellate Noctiluca scintillans that itself was cultured in the laboratory on either Prorocentrum micans or Af1719.

Experimental animals. All 4 crab species were collected in ovigerous state in the inland marine waters of the northern Puget Sound basin near the Shannon Point Marine Center in Anacortes, Washington. Larvae of Cancer magister and C. oregonensis hatch in early winter, with larvae of the latter species being generally more resistant to nutritional stress (Sulkin \& McKeen 1999). Larvae of these species are present in the water column during a period of very low primary productivity and may be particularly dependent on a source of microbial nutrition during the critical period of early development (Sulkin et al. 1998a). Larvae of Hemigrapsus oregonensis hatch in the summer, a period of comparatively high primary productivity and of frequent blooms of toxic algae including Alexandrium spp. Rhinolithodes wosnessenskii larvae have not been studied extensively, but typically hatch locally in the early spring (Haynes 1984). Their ingestion of protists was of interest because their nutritional needs contrast with those of the 3 brachyuran species.

Preparation and maintenance of diet treatments. Autotrophic dinoflagellates: Prorocentrum micans was cultured in $1 \mathrm{l}$ polycarbonate bottles in $\mathrm{f} / 2$ nutrient medium maintained at $22^{\circ} \mathrm{C}$ on a $12 / 12 \mathrm{~h}$ light/dark cycle. To maintain cells in growth phase and to normalize for the feeding experiments, cultures were maintained at an approximate cell density of $1000 \mathrm{ml}^{-1}$. Starter cultures were not axenic but contained no other algae. All 3 strains of Alexandrium were cultured using the same procedures.

Noctiluca scintillans: The heterotrophic dinoflagellate Noctiluca scintillans was cultured in 21 polycarbonate bottles filled with $0.2 \mu \mathrm{m}$ filtered seawater and a dilute EDTA-trace metal mix (Gifford 1985). Stock cultures were fed weekly on Prorocentrum micans. Before the ingestion experiments, a stock culture was taken off the $P$. micans diet and starved for $5 \mathrm{~d}$ to clear its food vacuoles of cells. The starved $N$. scintillans cells were then divided into 2 groups, 1 fed for 48 h on P. micans 
and the other on Af1719. Both algae were provided to $N$. scintillans at cell densities of $3000 \mathrm{ml}^{-1}$ from cultures grown to exceed that density. Twenty $N$. scintillans were selected randomly from each treatment for examination of their food vacuoles to insure that the cultures were actively feeding on the respective algal diets. $N$. scintillans cells were concentrated by reverse filtration ( $80 \mu \mathrm{m}$ sieve) for feeding to crab larvae.

Exudate preparations: To determine whether chemicals exuded by the various algae might have an influence on ingestion behavior, Prorocentrum micans cells were suspended in freshly prepared exudates of Af1719 (toxic) and At115 (non-toxic), while Alexandrium cells of both species were suspended separately in exudate from $P$. micans. All 3 cell types were gravity filtered from the growth medium (10 $\mu \mathrm{m}$ filter) to produce both exudate and isolated cells. $P$. micans cells were then suspended in either of the Alexandrium cell exudates and both Alexandrium cells were suspended separately in the $P$. micans exudate. Cell concentrations after suspension in exudate were approximately $1000 \mathrm{ml}^{-1}$. Because rapid lability of exuded Alexandrium toxin was reported by Hansen (1989), ingestion observations were made less than 1 min after exudate was isolated.

Combination treatments: To determine the effect of the presence of 1 algal species on the ingestion of the other, defined mixtures were fed to crab larvae. To produce the mixtures, stock cultures of target species were diluted to cell densities of $1000 \mathrm{ml}^{-1}$ and appropriate volumes of each were combined to produce the desired ratio at a total cell density of $1000 \mathrm{ml}^{-1}$. For example, a 1:1 ratio of Prorocentrum micans to At118 was produced by manipulating each stock culture to $1000 \mathrm{ml}^{-1}$, then combining equal volumes of the 2 stock cultures to provide the experimental diet. These 1:1 ratios of $P$. micans to Af1719, At115, and At118 were fed to larvae of all 3 brachyuran species. In addition, larvae of Hemigrapsus oregonensis were fed P. micans: Af1719 ratios of 1:2, 1:5, 1:10, 1:15, 1:20, and 1:30.

Additional experiments used plastic beads (Fluorosprite $25 \mu \mathrm{m}$ latex beads; Polysciences, Inc., Warrington, PA) either alone or in combination with Prorocentrum micans or Af1719 cells at a total cell (particle) density of $1000 \mathrm{ml}^{-1}$. Plastic beads were also suspended in freshly prepared exudate of either $P$. micans or Af1719 at a total particle count of $1000 \mathrm{ml}^{-1}$. Plastic microsphere experiments were carried out using larvae of Hemigrapsus oregonensis only.

Ingestion experiments. Ingestion was determined by examining the guts of selected larvae for presence of the target algal cells using an epifluorescence microscope. Individual larvae to be examined were removed by pipet from the feeding culture and placed on a microscope slide. Excess water was removed from the slide and the larvae were observed at $40 \times$. Ingestion was deemed to have occurred when there were at least 3 individual algal cells in the gut. In the vast majority of cases, the guts either contained many cells or were empty. Ingestion tests were identical for all treatments. Larvae used in the experiments had hatched during the previous $12 \mathrm{~h}$ and had not been fed. For each observation, larvae from at least 2 broods were pooled before selection of individual larvae for the experiment. For each test, 100 larvae were arbitrarily selected from a large pool of at least several hundred, were placed in one $80 \mathrm{~mm}$ diameter glass bowl, and were fed the target diet. At specified observation times, 15 larvae were selected haphazardly and observed as described above for evidence of prey cells in their guts. Larvae were discarded after observations. This experiment was repeated with 3 different groups of larvae, with treatment comparisons based on the percentage of larvae feeding in each experiment $(\mathrm{n}=3)$. Ingestion of single diet types and 1:1 ratios was typically observed at 3,6, 12, 24, 48, and $96 \mathrm{~h}$. Time intervals of observations for other experiments varied and are specified with the results.

In the Noctiluca scintillans experiment, a mixture of 10 cells fed Prorocentrum micans and 10 fed Af1719 was fed to each of 10 Hemigrapsus oregonensis larvae, each placed in a separate $10 \mathrm{~mm}$ diameter glass bowl for $8 \mathrm{~h}$. At the end of $8 \mathrm{~h}$, the remaining $N$. scintillans cells were examined and identified as to treatment. The experiment was repeated 3 times with different groups of larvae. The percentage of each type of $N$. scintillans cell ingested by each larva was determined and compared.

Larval survival and development rate experiments. To further assess the value of toxic and non-toxic strains of Alexandrium to crab larval development, larval cultures of the 2 Cancer spp. were maintained from hatching to molt to zoeal stage 2 on Af1719 and At115. An unfed treatment and a fed control consisting of freshly hatched nauplii of the brine shrimp Artemia spp. (Argentemium, Argent Chemical Laboratory, Redmont, WA) were also tested simultaneously. Algae were fed to the larvae at a concentration of 1000 cells $\mathrm{ml}^{-1}$ and Artemia spp. at $8 \mathrm{ml}^{-1}$.

Newly hatched larvae from at least 2 broods were pooled. Larvae were haphazardly selected from the pool and placed in plastic trays containing 12 individual cell wells, 1 larva well ${ }^{-1}$. Each well contained approximately $4 \mathrm{ml}$ of Alexandrium culture medium containing the algal cells. The unfed larvae were placed into culture medium with no prey present. Three trays (each containing 12 larvae) were haphazardly assigned to each of the 4 treatments and fed accordingly. Larvae were transferred daily to clean cell wells containing fresh medium with the appropriate diet. Mortality and evidence of molting to zoeal stage 
2 were noted daily. Treatment comparisons were based on whether the diet supported development to zoeal stage 2 and, if so, whether there was a difference in duration of the first zoeal stage. In treatments where there was no molting to zoeal stage 2, mean days of death were calculated and compared.

Because Rhinolithodes wosnessenskii larvae can develop to zoeal stage 2 without feeding, the experimental design for survival and development rate differed from that of the 2 Cancer spp. Mortality and percentage of larvae molting on unfed, freshly hatched Artemia spp. nauplii and Af1719 (1000 cells ml $\left.{ }^{-1}\right)$ treatments were compared on Day 5 of the culture. This day was selected as providing a sufficient feeding time for dietary effects to be evident, while providing an endpoint before $100 \%$ molting of unfed larvae. Larvae were obtained from 1 female and distributed among 9 trays, each containing 12 larvae. Three trays were haphazardly assigned to each diet treatment. Cultures were transferred daily to fresh medium containing the appropriate diet treatment.

Larvae of Hemigrapsus oregonensis were raised from hatching on the following diet treatments: unfed,

Table 1. Mean percentage of larvae that show ingestion of indicated prey types at each observation time. Af1719: Alexandrium fundyense 1719 (toxic); At115: A. tamarense 115 (non-toxic); At118: A. tamarense 118 (toxic); Pm: Prorocentrum micans. $\mathrm{n}=3$ for each observation time

\begin{tabular}{|lrrrr|}
\hline Crab species & \multicolumn{4}{c}{ Diet treatment } \\
Time interval & Pm & At118 & At115 & Af1719 \\
\hline Cancer oregonensis & & & & \\
3 & 90 & 0 & 0 & 71 \\
6 & 100 & 0 & 0 & 100 \\
12 & 100 & 0 & 0 & 75 \\
24 & 100 & 0 & 0 & 34 \\
48 & 95 & 0 & 0 & 0 \\
96 & 100 & 0 & 0 & 4 \\
Cancer magister & & & & \\
3 & 95 & 0 & 0 & 0 \\
6 & 100 & 2 & 0 & 0 \\
12 & 100 & 0 & 0 & 0 \\
24 & 100 & 3 & 3 & 2 \\
48 & 100 & 0 & 0 & 0 \\
96 & 100 & 0 & 0 & 0 \\
Hemigrapsus oregonensis & & & \\
3 & 100 & 0 & 0 & 0 \\
6 & 100 & 0 & 0 & 0 \\
12 & 100 & 0 & 0 & 0 \\
24 & 100 & 0 & 0 & 0 \\
48 & 100 & 0 & 0 & 0 \\
96 & 100 & 0 & 0 & 0 \\
Rhinolithodes wosnessenskii & & & \\
3 & 100 & - & 0 & 0 \\
6 & 100 & - & 0 & 0 \\
12 & 100 & - & 0 & 0 \\
24 & 100 & - & 0 & 0 \\
48 & 100 & - & 0 & 0 \\
96 & 100 & - & 0 & 0 \\
& & & & \\
\hline
\end{tabular}

AF1719 at 1000 cells ml ${ }^{-1}, 1: 1$ combination ratio of Prorocentrum micans:Af1719 at 500 cells ml $^{-1}$ each (total density of $1000 \mathrm{ml}^{-1}$ ), and $P$. micans only at the reduced dosage of 500 cells $\mathrm{ml}^{-1}$. Larvae were obtained from 1 female crab and distributed among 3 cell well trays for each diet treatment $\left(n=36\right.$ larvae treatment $\left.{ }^{-1}\right)$. Larvae were transferred daily to fresh medium and fed the appropriate diet. Survival was monitored, with mean days of death compared among the treatments.

\section{RESULTS}

\section{Ingestion of individual diets}

Prorocentrum micans were ingested by virtually all larvae at all observation times in all 4 species tested (Table 1). Cells were present in 90 to $100 \%$ of the larvae at the first $(3 \mathrm{~h})$ measurement and guts remained filled with $P$. micans throughout the $96 \mathrm{~h}$ period of the experiment.

By contrast, both non-toxic (At115) and toxic (At118, Af1719) strains of Alexandrium were almost never ingested by any species at any observation time (Table 1). Only in Cancer oregonensis was ingestion of Alexandrium cells noted and only of the toxic Af1719 strain (Table 1). In this case, there was initial ingestion of cells, with $100 \%$ of the larvae feeding by $6 \mathrm{~h}$, followed by a rapid decline in ingestion such that by $48 \mathrm{~h}$, no larvae were found to have Af1719 cells in their guts.

The effects of raising Cancer oregonensis and $C$. magister larvae on Prorocentrum micans and Alexandrium strains generally confirmed the ingestion results. C. oregonensis larvae fed the control diet of freshly hatched Artemia spp. nauplii showed 93\% survival to zoeal stage 2 with a mean stage duration of $10.9 \pm 1.1 \mathrm{~d}$ (mean $\pm \mathrm{SE}$ ). Unfed larvae and those fed the non-toxic At115 or the toxic Af1719 all died before molting to zoeal stage 2 . No significant differences in mean days of death were found among these 3 treatments (Table 2 ; ANOVA, p > 0.05), suggesting that the Alexandrium cells were not contributing nutritionally. Although the ingestion experiments suggested that larvae did feed

Table 2. Cancer spp. Mean \pm SE days of death for first stage larvae of the 2 species fed the indicated diets. No significant differences were found among treatments for either species $($ ANOVA, $p>0.05)$. Initial sample size $=36$ for each treatment. See Table 1 for definitions of diet treatments

\begin{tabular}{|lcc|}
\hline \multirow{2}{*}{ Diet } & \multicolumn{2}{c|}{ Crab species } \\
& C. oregonensis & C. magister \\
\hline Af1719 & $12.8 \pm 0.56$ & $5.6 \pm 0.54$ \\
At115 & $13.8 \pm 0.73$ & $7.8 \pm 0.30$ \\
Unfed & $11.6 \pm 0.24$ & $5.4 \pm 0.19$ \\
\hline
\end{tabular}


briefly on Af1719 cells, there is no evidence that such feeding resulted in a delay in mortality.

Results with Cancer magister larvae were similar. Larvae fed the brine shrimp nauplius control developed successfully to zoeal stage 2 (60\% survival; mean \pm SE stage duration $8.4 \pm 1.0 \mathrm{~d}$ ). There was no significant difference in mean days of death among the unfed and 2 Alexandrium-fed treatments (Table 2; ANOVA, $\mathrm{p}>0.05)$. Again, there is no evidence that sustained exposure to either Alexandrium diet resulted either in nutritional benefit or toxicity to the larvae.

Results from the facultative planktotroph Rhinolithodes wosnessenskii provided an interesting contrast with the 2 Cancer spp. On Day 5, there were significant differences among treatments in percentage mortality (Table 3; ANOVA on arcsine transformed data, $\mathrm{p}<0.05)$. Results of a Tukey's honestly significant difference (HSD) test (Table 3) show a higher mortality for unfed larvae than for larvae fed either Artemia nauplii or AT1719. There were also significant differences among treatments in mean percentage molting on Day 5 (Table 3; ANOVA on arcsine transformed data, $\mathrm{p}<0.05$ ), with feeding on brine shrimp nauplii accelerating development, while feeding on Af1719 delaying it compared with the unfed treatment (Tukey's HSD test, $\mathrm{p}=0.05)$. These results imply that at least a few of the larvae were feeding on Af1719 either throughout the experiment in contrast to the direct observations on ingestion (Table 1) or after 96 h (e.g. Day 5).

\section{Combination diets}

When Prorocentrum micans was presented to larvae of all 3 species of brachyuran crabs in a 1:1 ratio with any of the 3 Alexandrium strains, nearly $100 \%$ of the larvae ingested algal cells at all observation times (Table 4). Furthermore, direct observations revealed that in all cases both algal species were being ingested.

To further elucidate this observation, larvae of Hemigrapsus oregonensis were fed diets consisting of a range of Prorocentrum micans:Af1719 ratios as described earlier. Incidence of ingestion was observed at $8 \mathrm{~h}$. The percentage of larvae feeding began to decline at a ratio of 1:10 (Fig. 1), dropping to less than $50 \%$ feeding at a ratio of $1: 20$, with less than $5 \%$ feeding at a ratio of 1:30. Again, in all cases where ingestion was noted, both algal species were present in the guts.

When Hemigrapsus oregonensis larvae were raised in laboratory culture on the 1:1 ratio of Prorocentrum micans:Af1719, there was a significant delay in mortality compared with an unfed treatment or with larvae fed only Af1719 (Table 5; ANOVA, p < 0.05; Tukey's HSD, $p=0.05)$. As anticipated from the ingestion observations, there was no delay in mortality on the latter
Table 3. Rhinolithodes wosnessenskii. Mean percentage mortality (A) and percentage molt (B) of stage 1 larvae on Day 5 on indicated diet treatments. Shared letter indicates no significant difference $(p=0.05)$ for each measurement

\begin{tabular}{|lccc|}
\hline A & & & \\
Diet & Mortality (\%) & SE & Tukey's HSD \\
\hline Unfed & 26 & 0.47 & a \\
Artemia spp. & 10 & 0.20 & b \\
Af1719 & 8 & 0.61 & b \\
B & & & \\
Diet & Molt (\%) & SE & Tukey's HSD \\
\hline Artemia spp. & 65 & 0.12 & a \\
Unfed & 32 & 0.29 & b \\
Af1719 & 17 & 0.43 & c \\
\hline
\end{tabular}

diet compared with the unfed control. Larvae fed the $P$. micans diet at 500 cells $\mathrm{ml}^{-1}$ did not survive to zoeal stage 2 in this experiment. However, adding Af1719 at 500 cells $\mathrm{ml}^{-1}$ to $P$. micans at 500 cells $\mathrm{ml}^{-1}$ neither accelerated nor delayed mortality.

\section{Exudate experiments}

To determine whether the differences in incidence of ingestion between the Prorocentrum micans diet and the Alexandrium strains were due to chemical stimuli produced by the latter, $P$. micans cells were suspended

Table 4. Mean percentage of larvae that show ingestion of indicated 1:1 ratio combinations of prey types for specified crab species. See Table 1 for definitions of diet treatments

\begin{tabular}{|c|c|c|c|}
\hline \multirow{2}{*}{$\begin{array}{l}\text { Crab species } \\
\text { Time interval }\end{array}$} & \multicolumn{3}{|c|}{ Diet Treatment } \\
\hline & Pm/At115 & Pm/Af1719 & Pm/At118 \\
\hline \multicolumn{4}{|c|}{ Cancer oregonensis } \\
\hline 3 & 90 & 100 & 100 \\
\hline 6 & 90 & 95 & 90 \\
\hline 12 & 90 & 90 & 90 \\
\hline 24 & 95 & 90 & 90 \\
\hline 48 & 100 & 88 & 90 \\
\hline 96 & 100 & 100 & 90 \\
\hline \multicolumn{4}{|l|}{ Cancer magister } \\
\hline 3 & 100 & 100 & 100 \\
\hline 6 & 100 & 95 & 90 \\
\hline 12 & 85 & 90 & 90 \\
\hline 24 & 100 & 90 & 90 \\
\hline 48 & 100 & 88 & 90 \\
\hline 96 & 100 & 100 & 90 \\
\hline \multicolumn{4}{|c|}{ Hemigrapsus oregonensis } \\
\hline 3 & 90 & 100 & 90 \\
\hline 6 & 90 & 100 & 100 \\
\hline 12 & 90 & 100 & 90 \\
\hline 24 & 95 & 100 & 100 \\
\hline 48 & 100 & 90 & 100 \\
\hline 96 & 100 & 100 & 100 \\
\hline
\end{tabular}




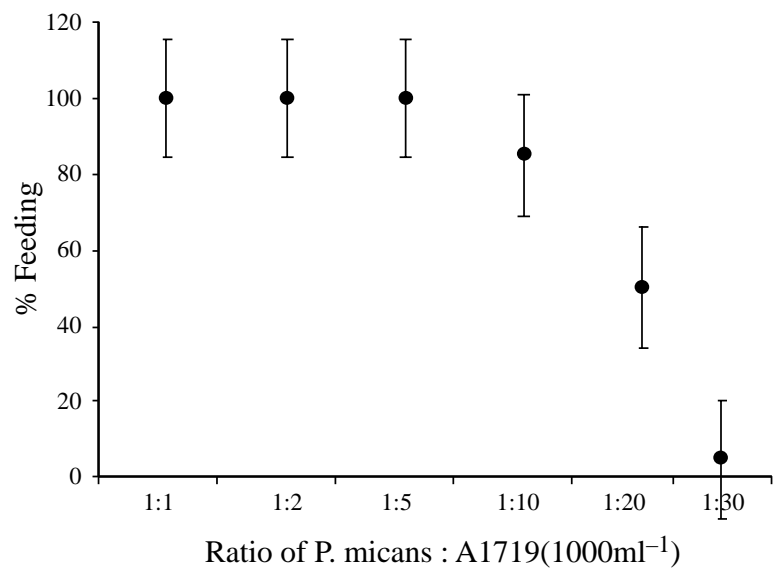

Fig. 1. Percentage of Hemigrapsus oregonensis larvae feeding on indicated ratios of Prorocentrum micans:Alexandrium fundyense 1719 (Af1719) cells. Total cell density is $1000 \mathrm{ml}^{-1}$

Table 5. Mean \pm SE day of death for Hemigrapsus oregonensis larvae fed the indicated diets. There were significant differences among treatments (ANOVA, $\mathrm{p}<0.05$ ). Shared letters indicate no significant differences (Tukey's HSD, $\mathrm{p}=0.05$ ). See Table 1 for definitions of diet treatments. $\mathrm{n}$ : numbers of larvae. Total cell counts at $1000 \mathrm{ml}^{-1}$ except Pm

\begin{tabular}{|lccc|}
\hline Diet & Mean day of death & $\mathrm{n}$ & Tukey's HSD \\
\hline Af1719 & $5.3 \pm 0.15$ & 36 & $\mathrm{a}$ \\
Unfed & $5.8 \pm 0.25$ & 36 & $\mathrm{a}$ \\
Pm/Af1719 (1:1) & $8.2 \pm 0.46$ & 36 & $\mathrm{~b}$ \\
Pm $\left(500 \mathrm{ml}^{-1}\right)$ & $9.2 \pm 0.47$ & 34 & $\mathrm{~b}$ \\
\hline
\end{tabular}

Table 6. Mean percentage of larvae that showed evidence of ingestion of indicated prey-exudate combinations at each observation time. See Table 1 for definitions of diet treatments. Ex: exudates. $\mathrm{n}=3$ in each case

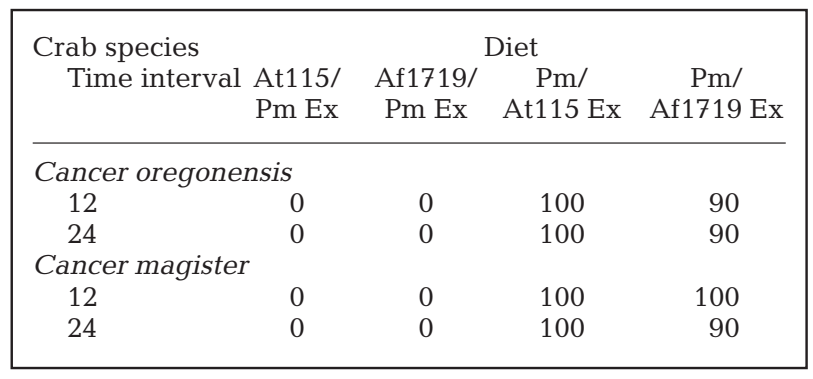

in freshly prepared exudate of the non-toxic At115 and the toxic Af1719 as described above. In both Cancer spp., incidence of $P$. micans ingestion was close to $100 \%$ in the exudates of the 2 Alexandrium strains (Table 6). When Af1719 and At115 cells were suspended in $P$. micans exudate, there was no incidence of ingestion (Table 6). Thus, the stimulus to feed on $P$. micans is not affected by the presence of Alexandrium exudates, nor are Alexandrium cells rendered more palatable by the presence of $P$. micans exudate.

\section{Ingestion of plastic beads}

When Hemigrapsus oregonensis larvae were given plastic beads alone, very few fed on them (Table 7). However, when the beads were provided in combination with Prorocentrum micans cells at a ratio of $1: 1$ (total particle concentration of $1000 \mathrm{ml}^{-1}$ ), $58 \%$ of the larvae ingested both particle types. Furthermore, when beads were presented to larvae in combination with Af1719 cells or suspended in either P. micans or Af1719 exudate, there was low incidence of ingestion. As was the case with Alexandrium cells, plastic beads were ingested most readily when combined with $P$. micans cells.

\section{Ingestion of Noctiluca scintillans}

Noctiluca scintillans cultured on either Prorocentrum micans or Af1719 were readily ingested by Hemigrapsus oregonensis larvae. When the 2 diet treatments were offered to larvae in combination, $90 \%$ of the Af1719-fed and $93 \%$ of the P. micans-fed N. scintillans were ingested, with no significant difference between treatments (Student's $t$-test on arcsine transformed data, $\mathrm{p}>0.05$ )

\section{DISCUSSION}

Virtually all larvae of all 4 species of crabs ingested Prorocentrum micans, while there was almost universal failure of larvae to ingest any strain of Alexandrium. This indicates some level of discrimination in feeding on algal cells by crab larvae.

For larvae to discriminate among prey, they must respond to prey-associated cues, presumably either chemical or mechanical stimuli. The mechanism by which crab larvae ingest captured protist cells is not well described. Sulkin et al. (1998a) described brachyuran larvae as 'encounter feeders'; that is, larvae grasp prey particles, both living and non-living (detritus), as both predator and prey move through the

Table 7. Mean percentage of Hemigrapsus oregonensis larvae feeding on plastic beads and algal mixtures after $8 \mathrm{~h}$ of exposure to the specified diets. See Table 1 for definitions of diet treatments. Ex: exudate. $\mathrm{n}=3$ in each case

\begin{tabular}{|lcc|}
\hline Diet treatment & Feeding (mean \%) & SE \\
\hline Beads alone & 5 & 0.11 \\
Beads + Pm & 58 & 0.23 \\
Beads + Af1719 & 3 & 0.26 \\
Beads + Pm Ex & 12 & 0.43 \\
Beads + Af1719Ex & 8 & 0.21 \\
\hline
\end{tabular}


water. Prey capture by crab larvae does not appear to require use of their well-developed eyes (Harvey \& Epifanio 1997, Sulkin et al. 1998a) and occurs over a wide range of prey sizes (from at least 5 to $250 \mu \mathrm{m}$; Lehto et al. 1998). Larger prey typically are grasped by the endites of the maxillules and pushed toward the mandibles where they are masticated and ingested (Crain 1999). It is possible that the protist Noctiluca, being as large as the largest metazoan prey typically used in laboratory culture of crab larvae, are handled in a similar way. Crain (1999) described capture and handling of the smaller Prorocentrum micans cells by the anomuran crab Placetron wosnessenskii as a 'fling and clap' motion (as described by Koehl \& Strickler 1981) in which the mouthparts first are swung rapidly outward, drawing the cell toward the mouth, then are rapidly drawn in, enclosing the cell. A similar activity was noted in the present study when larvae ingested P. micans, but not when they were presented with Alexandrium spp. In the latter case, larvae pushed the Alexandrium cell toward the mandibles, which pulled the cell in toward the mouth, then pushed it away.

Thus, larvae appeared to require intimate contact with the target cell before ingestion was stimulated. This is consistent with the lack of stimulus provided by the exudate and with the speculation by Teegarden \& Cembella (1996) that copepods make prey ingestion decisions by recognizing cues either on the surface of the cell or in an associated fluid microzone around the cell. Both Alexandrium tamarense and Prorocentrum micans have lectin molecules on the cell surface (Hori et al. 1996). It is possible that a lectin or other molecule(s) associated with the cell surface play a role in prey discrimination on the part of larvae.

The nature of a prey-associated ingestion cue might be positive (stimulating ingestion) or negative (stimulating rejection). The preponderance of evidence suggests that a positive stimulus was controlling ingestion of protists in the present study. This conclusion is supported by the observation that while Alexandrium spp. cells were not ingested, both Prorocentrum micans and Noctiluca scintillans were, the latter whether it had previously been fed either P. micans or Af1719. Furthermore, larvae ingested all 3 strains of Alexandrium, as well as inert plastic beads when they were combined with comparatively few $P$. micans cells. Thus, Alexandrium cells did not appear to produce a cue that induced rejection on the part of the larval predator, since they were ingested when combined with $P$. micans cells or when inside the food vacuoles of $N$. scintillans. The ingestion of both Alexandrium cells and plastic beads when each was combined with $P$. micans further suggests that once feeding is induced by a positive stimulus, such as that produced by $P$. micans, larvae cease to discriminate between cell types. While this scenario seems the most likely, the results do not rule out the possibility that Alexandrium cells do produce a rejection cue that is readily overridden by the presence of a positive cue produced by another alga. In either case, however, the positive stimulus dominates the process.

Clearly, the failure of larvae to ingest non-toxic as well as toxic strains of Alexandrium precludes the possibility that Alexandrium-produced toxin prevented ingestion of cells by larvae. Furthermore, placing larvae in exudate freshly prepared from either a favorable or an unfavorable prey had no effect on their ingestion behavior. The results thus do not support the role of a water-borne chemical stimulus, either positive or negative. It is possible, however, that the presumed cue on the prey cell surface is chemical in nature.

Larvae of Cancer oregonensis did ingest Alexandrium fundyense cells, at least initially. Because $C$. oregonensis did not ingest either non-toxic or toxic strains of $A$. tamarense and because other crab species, including the congener $C$. magister, did not ingest $A$. fundyense, this result appears to be a species-specific phenomenon for either the predator, the prey, or both. Cancer oregonensis has been shown to be more nutritionally flexible than its congener (Sulkin \& McKeen 1999) and may be able to consume a wider variety of prey. It is interesting to note, however, that the percentage of larvae that showed evidence of having ingested this toxic strain declined over time. Presumably, the presence of toxin or some other factor resulted in larvae ceasing to ingest this prey after a period of exposure. Unfortunately, there is no nontoxic strain of $A$. fundyense available to rigorously test the role played by the toxin in this behavior.

Given the absence of ingestion of Alexandrium cells by the larvae, it is not surprising that this diet did not support development and that there was no delay in mortality compared with unfed controls in either Cancer species. Inducing Hemigrapsus oregonensis larvae to ingest the toxic strain of $A$. fundyense by combining it with Prorocentrum micans neither accelerated nor delayed mortality compared with presenting the larvae with a sub-optimal dosage of $P$. micans alone. This suggests that ingestion of toxic strains of an alga that does not itself stimulate predation had no deleterious effect on the larval predator. Only in the anomuran facultative planktotroph Rhinolithodes wosnessenskii did extended exposure to toxic Alexandrium have an effect. However, even in this case, results were mixed; a reduction in mortality was combined with a delay in development compared with the unfed control.

Larvae in nature are almost always faced with a complex mixture of prey. Feeding is likely to occur if the mixture includes sufficient quantities of prey that produce positive stimuli for ingestion. Moreover, if the 
mixture does include sufficient quantities of such prey, larvae are also likely to ingest prey particles that do not provide this positive stimulus. This lack of discrimination in prey selection when favorable prey are present may promote rapid ingestion of available particles when larvae encounter dense patches of prey in an otherwise sparse prey environment.

It also seems likely that larvae do not feed when they find themselves in dense aggregates of prey dominated by unfavorable and possibly toxic blooms of algae. However, even harmful algal blooms, although consisting of only a few species at the bloom center, do sustain a more diverse community, including heterotrophic protists, at the periphery (Turner \& Tester 1997). Thus, a prey field may develop at the periphery of such an algal bloom that is likely to be a favorable feeding environment for crab larvae.

Crab larvae, while they are omnivores that ingest a wide variety of prey types including metazoans, protists, and microbially colonized detrital particles, nevertheless appear to discriminate among prey. At least for such small prey as protists, the discriminatory behavior seems to require testing of individual cells. It has yet to be determined whether there is a relation between the presence of a positive prey-associated cue and the qualitative value of that prey as a nutritional source.

Acknowledgements. This manuscript includes data submitted in partial fulfillment of the Master of Science degree at Western Washington University by the first author. The first author was supported by graduate assistantships provided by the Shannon Point Marine Center and by assistance from NSF Grant No. OCE-9729316. The fourth author was supported by NSF Grant No. OCE-9731144.

\section{LITERATURE CITED}

Anger K, Dawirs R (1981) Influence of starvation on the larval development of Hyas araneus (Decapoda; Majidae). Helgol Wiss Meeresunters 34:287-311

Crain JA (1999) Functional morphology of prey ingestion by Placetron wosnessenskii schalfeew zoeae. Biol Bull 197: 207-218

Damkaer D (1977) Initial zooplankton investigations in Prince William Sound, Gulf of Alaska and Lower Cook Inlet. In: Environmental assessment of the Alaskan continental shelf: annual reports of the principal investigators for the year ending March, 1977, Vol. 10. Receptors-Fish, Littoral, Benthos. RU-425. US Department of Commerce, Boulder, CO, p 137-274

Gifford DJ (1985) Laboratory culture of marine planktonic oligotrophs (Ciliophore, Oligotrichida). Mar Ecol Prog Ser 23:257-267

Hansen PJ (1989) The red tide dinoflagellate Alexandrium tamarense: effects on behavior and growth of tintinnid ciliate. Mar Ecol Prog Ser 53:105-116

Editorial responsibility: Michael Landry (Contributing Editor), Hawaii, Honolulu, USA
Hartman M, Sulkin S (1999) Effects of prior exposure to petroleum hydrocarbon contamination during brooding on the subsequent larval development of the brachyuran crab Hemigrapsus oregonensis. J Crustac Biol 19:690-698

Harvey EA, Epifanio CE (1997). Prey selection by larvae of the common mud crab Panopeus herbstii Milne-Edwards. J Exp Mar Biol Ecol 217:79-91

Haynes EB (1984) Early zoeal stages of Placetron wosnessenskii and Rhonolithodes wosnessenskii and review of Lithodid larvae of the northern North Pacific Ocean. Fish Bull 82:315-324

Hori K, Mimuro M (1996) Lectin-like compounds and lectin receptors in marine microalgae hemagglutination and reactivity with purified lectins. J Phycol 32:783-790

Koehl M, Strickler R (1981) Copepod feeding currents: food capture at low Reynolds number. Limnol Oceanogr 26: 1062-1073

Lehto J, Sulkin S, Strom S, Johnson D (1998) Protists and detrital particles as prey for the first larval stage of the brachyuran crab, Hemigrapsus oregonensis. J Exp Mar Biol Ecol 230:213-224

Levine DM, Sulkin S (1984) Nutritional significance of longchain polyunsaturated fatty acids to the zoeal development of the brachyuran crab, Eurypanopeus depressus. J Exp Mar Biol Ecol 81:211-223

Paul AJ, Paul JM, Shoemaker PA, Feder HM (1979) Prey concentrations and feeding responses in laboratory-reared stage-one zoeae of King crab, Snow crab, and Pink shrimp. Trans Am Fish Soc 108:440-443

Paul AJ, Paul JM, Coyle K (1989) Energy sources for first-feeding zoeae of king crab Paralithodes camtschatica (Tilesius) (decapoda, Lithodidae). J Exp Mar Biol Ecol 130:55-69

Staton J, Sulkin S (1991) Nutritional requirements and starvation resistance in larvae of the brachyuran crabs Sesarma cinereum (Bosc) and S. reticulatum (Say). J Exp Mar Biol Ecol 152:271-284

Sulkin S (1975) The significance of diet in the growth and development of larvae of the blue crab, Callinectes sapidus, under laboratory conditions. J Exp Mar Biol Ecol 20:119-135

Sulkin S, McKeen G (1999) The significance of feeding history on the value of heterotrophic microzooplankton as prey for larval crabs. Mar Ecol Prog Ser 186:219-225

Sulkin SD, van Heukelem WF (1980) Ecological and evolutionary significance of nutritional flexibility in planktonic larvae of the deep sea red crab Geryon guinquedens and the stone crab Menippe mercenaria. Mar Ecol Prog Ser 2: 91-95

Sulkin SD, Blanco A, Chan J, Bryant M (1998a) Effects of limiting access to prey development of first zoeal stage of the Brachyuran crabs Cancer magister and Hemigrapsus oregonensis. Mar Biol 131:515-521

Sulkin S, Lehto J, Strom S, Hutchinson D (1998b) Nutritional role of protists in the diet of first stage larvae of the Dungeness crab Cancer magister. Mar Ecol Prog Ser 169: 237-242

Teegarden GJ, Cembella AD (1996) Grazing of toxic dinoflagellates, Alexandrium spp., by adult copepods of coastal Maine: implications for the fate of paralytic shellfish toxins in marine food webs. J Exp Mar Biol Ecol 196: 145-176

Turner JT, Tester PA (1997) Toxic marine phytoplankton, zooplankton grazers, and pelagic food webs. Limnol Oceanogr 42:1203-1214

Submitted: October 30, 2000; Accepted: March 22, 2001

Proofs received from author(s): October 26. 2001 